\section{A regionalização assistencial no aperfeiçoamento das ações integradas de saúde.}

A VIII Conferência Nacional de Saúde apontou, como uma de suas conclusões, que a mudança do Sistema Nacional de Saúde é parte importante do processo de redemocratiza. ção de nosso país.

Nesse sentido colocou, como uma situação-objetivo a ser alcançado, a proposta da Reforma Sanitária que irá viabili. zar um sistema universalizado e igualitário, como decorrência do compromisso político da Nova República - inscrito no I Plano Nacional de Desenvolvimento - de considerar a saúde como direito do cidadão e dever do Estado.

O momento exige reforçar as Ações Integradas de Saúde como a estratégia de reformulação do Sistema Nacional de Saúde, o que irá permitir, a curto e médio prazos, a superação da atual forma de organização plural e desintegrada por uma outra que, respeitando as identidades organizacionais, coloque sob gestão pública todas as instituições relacionadas com o setor público, integrando-as, em todas as suas atividades e com todos os seus recursos, de modo a que possam responder às necessidades prioritárias da população.

Resulta daí uma necessária reafirmaçâao da vontade política de consolidação das Ações Integradas de Saúde como o eixo estratégico da Reforma Sanitária, fazendo-as avançar concretamente, para além de uma simples relação convenial entre entidades do setor público.

Isso significará decodificá-las, doutrinária e operativamente, como instrumentos de reorganização dos serviços de saúde, o que remete à questão essencial da formulação e implantação de modelos assistenciais.

A pluralização se justifica pelo fato de que, num país continental como o Brasil, não se poderá pensar num modelo assistencial único mas, ao contrário, em diferentes modos organizacionais referidos por uma concepção nacional global, porém, adaptados às respectivas realidades regionais.

É por isso que se torna imprescindivel trabalhar imedia. tamente, e aproveitando os espaços políticos, jurídicos e institucionais criados pela transição democrática, no sentido da construção, de baixo para cima, de modelos assistenciais que incorporem, gradativamente, nas suas materialidades, a doutrina e os princípios da Reforma Sanitária.

$O$ objetivo principal desses novos modelos assistenciais passa a ser a criação de uma identidade reciproca entre os serviços e a população, onde haja uma mútua transparência, resgatando-se as pessoas como sujeitos dos serviços a elas oferecidos, e não como meros objetos.

Cadernos de Saúde Rública, R.J., 2 (3): 273-278, jul/s't. 1986.
Recébido para publicação cm 29/09/86 
De tal forma que a população reconheça nos serviços os "seus" serviços, e os serviços, na população, a "sua" população, criando-se, assim, uma identificação que, de um lado, permitirá a abordagem epidemiológica e, de outro, o controle social dos serviços.

Para que isso possa ocorrer, torna-se necessário reconceber o processo de regionalização que vem sendo adotado em nosso país.

Uma análise crítica da experiência brasileira de regiona. lização vai mostrar que esse movimento se efetivou, exclusivamente, numa perspectiva político-administrativa, tendo, por conseqüência, baixo impacto sobre a rede de serviços.

Impõe-se repensar essa regionalização administrativa, transformando-a numa regionalização assistencial que tenha como objetivo principal reorganizar os serviços e torná-los eficazes e eficientes.

Daí colocar-se, como a base da organização espacial e funcional do novo sistema, o distrito sanitário, entendido como o módulo, determinado geograficamente, de composição institucional plural e com algum grau de autonomia decisória, onde se desenvolverá o conjunto das ações básicas de saúde, apoiadas por ambulatório especializado e hos. pital geral.

Essa proposta de construção ascendente e gradual da Reforma Sanitária, para ter conseqüência, precisa ser informada por alguns princípios e diretrizes gerais.

A coerência doutrinária vai implicar que os modelos assis. tenciais sejam universalizados, equalizados e organizados por níveis de atenção. Ou seja, que garantam a quaisquer pessoas, de quaisquer localidades, através de sistemas de referência e contra-referência, acesso a todos os níveis de complexidade tecnológica.

Também, a viabilização desses modelos assistenciais vai exigir uma mudança básica na qualidade do planejamento de saúde que, em função do centralismo autoritário, transformou-se num planejamento exógeno com o único objetivo de captar recursos de entidades externas ao processo de produção de serviços. Urge adequar o planejamento para que cumpra o seu papel na reorganização dos serviços, o que vai implicar uma valorização relativa da atitude estraté. gica e da programação local integrada, elaborada a partir de critérios epidemiológicos.

Do ponto de vista gerencial, é fundamental que se considere a gestão colegiada, porém com mando único, a fim de que as responsabilidades institucionais possam ser identificadas pela população. Trata-se de dar rosto aos serviços de saúde.

Além disso, deverá haver uma adequação das instâncias gestoras das Ações Integradas de Saúde aos novos modelos 
assistenciais com a conseqüente redefinição de papéis, composição e mecanismos de funcionamento.

Os distritos sanitários deverão superar, na concretude de seus serviços, a artificial e deliberada dicotomia entre "atenção médica" ou "atenção à saúde das pessoas" e "saúde pública" ou "saúde coletiva".

Assim, é preciso obedecer ao princípio da integralidade da atenção através do qual aquela falsa divisão desapareça pelo pronto atendimento à demanda espontânea - o fator de legitimação social dos serviços - e a inserção de determinadas condições ou agravos em atividades de oferta organizada - o fator de legitimação epidemiológica. Ademais, a integralidade vai conduzir ao desenvolvimento, a nível de distrito sanitário, de atividades de vigilância sanitária e de controle de endemias e do meio ambiente.

A possibilidade de uma oferta organizada de serviços para condições e agravos passíveis de uma ação ativa e periódica impõe a necessidade de algum tipo de adscrição de clientela, seja individual, familiar ou geográfica.

O princípio da descentralização administrativa coloca como imprescindível e politicamente urgente a municipalização das ações de saúde.

Não há que se obstar a essa evidência, mas a questão deveria ser recolocada como a necessidade da restauração do poder local num quadro mais geral de redefinição dos papéis das diversas instâncias governamentais, sob a égide de uma reforma fiscal que compatibilize obrigações trans. feridas e recursos.

Mesmo porque, algumas vezes, os limites de um distrito sanitário irão transcender um município para se confundir com uma microrregião.

De início, os modelos assistenciais deverão prever, na sua concepção, segundo as prioridades definidas nas Ações Integradas de Saúde, a participação de instituições filantró. picas, o que vai implicar uma reorientação das ações dessas organizaçóes que não atuarão isoladamente, mas como parte do modelo assistencial, em um espaço determinado.

$O$ que significa inserílas na rede hierarquizada de serviços, colocá-las sob a gestão das Ações Integradas de Saúde e programá-las segundo critérios epidemiológicos.

Neste momento, assume grande relevância política, a implantação imediata do convênio-padrão com as entidades beneficentes ou filantrópicas, o que equivale a reconhecé. las, de direito e de fato, como entes públicos de caráter não-estatal.

Os modelos assistenciais deverão buscar formas democráticas que permitam o efetivo controle da população sobre os serviços.

Tal controle deve ser exercido pela sociedade civil orga- 
nizada, mediante participaçäo direta ou delegada e/ou mecanismos de pressão, nas diversas instâncias gerenciais ou operativas do sistema de saúde, especialmente a nível do distrito sanitário.

E será a possibilidade mesma desse controle social que vai imprimir a um sistema universalizado e equalizado o seu conteúdo democrático.

Assim concebidos e implantados, tais modelos assistenciais estarão coerentes com o espírito da Nova República, com os princípios da Reforma Sanitária e com a estratégia de Ações Integradas de Saúde.

Tais idéias, já maduramente refletidas, estão a exigir uma firme decisão política de implementá-las. Ou seja, uma opção por fazer, agora.

Isso leva ao estabelecimento de uma estratégia de implantação dos novos modelos assistenciais que poderá, a grosso modo, guiar-se pelos seguintes passos táticos:

1. homogeneizar e difundir conceitos relativos à interpretação das Ações Integradas de Saúde como estratégia e seus modelos assistenciais, principalmente e concepção de distrito sanitário. A concretização desse passo irá exigir um amplo processo de mobilização nacional envolvendo Ministérios, INAMPS, Secretarias estaduais e municipais, entidades filantrópicas, prestadores e usuários dos serviços;

2. delinear a metodologia de definição dos distritos sanitários;

3. definir, nas unidades federadas, imediatamente, todos os seus distritos sanitários;

4. adaptar os instrumentos de políticas institucionais às exigências dos novos modelos assistenciais. Uma ênfase especial deve ser dada à Programação - Orçamentação Integrada de 1987 (POI/87) que deverá, obrigatoriamente, ter como objeto programático o distrito sanitário;

5. escolher, em cada unidade federada, um conjunto de dis. tritos sanitários que serão objeto de uma concentração relativa de esforços de planejamento, acompanhamento e avaliação, sem que isso signifique uma opção por projetospiloto. A seleção desses distritos sanitários poderá envolver, dentre outras, as variáveis de tipicidade dentro do estado e viabilidades política e técnica.

\section{Roberto Figueira Santos Ministro da Saúde}

